\title{
Inhibition of Connexin 26/43 and Extracellular-Regulated Kinase Protein Plays a Critical Role in Melatonin Facilitated Gap Junctional Intercellular Communication in Hydrogen Peroxide-Treated HaCaT Keratinocyte Cells
}

\author{
Hyo-Jung Lee, ${ }^{1}$ Hyo-Jeong Lee, ${ }^{1}$ Eun Jung Sohn, ${ }^{1}$ Eun-Ok Lee, ${ }^{1}$ Jin-Hyoung Kim, ${ }^{1}$ \\ Min-Ho Lee, ${ }^{2}$ and Sung-Hoon Kim ${ }^{1}$ \\ ${ }^{1}$ College of Oriental Medicine, Kyung Hee University, 1 Hoegi-dong, Dongdaemun-gu, Seoul 131-701, Republic of Korea \\ ${ }^{2}$ College of Life Sciences and Biotechnology, Kyung Hee University, Yongin 446-701, Republic of Korea
}

Correspondence should be addressed to Sung-Hoon Kim, sungkim7@khu.ac.kr

Received 26 August 2012; Accepted 26 September 2012

Academic Editor: Y. Ohta

Copyright (C) 2012 Hyo-Jung Lee et al. This is an open access article distributed under the Creative Commons Attribution License, which permits unrestricted use, distribution, and reproduction in any medium, provided the original work is properly cited.

\begin{abstract}
Though melatonin was known to regulate gap junctional intercellular communication (GJIC) in chick astrocytes and mouse hepatocytes, the underlying mechanism by melatonin was not elucidated in hydrogen peroxide- $\left(\mathrm{H}_{2} \mathrm{O}_{2}-\right)$ treated $\mathrm{HaCaT}$ keratinocyte cells until now. In the current study, though melatonin at $2 \mathrm{mM}$ and hydrogen peroxide $\left(\mathrm{H}_{2} \mathrm{O}_{2}\right)$ at $300 \mu \mathrm{M}$ showed weak cytotoxicity in $\mathrm{HaCaT}$ keratinocyte cells, melatonin significantly suppressed the formation of reactive oxygen species (ROS) in $\mathrm{H}_{2} \mathrm{O}_{2}$-treated $\mathrm{HaCaT}$ cells compared to untreated controls. Also, the scrape-loading dye-transfer assay revealed that melatonin enhances the intercellular communication by introducing Lucifer Yellow into $\mathrm{H}_{2} \mathrm{O}_{2}$-treated cells. Furthermore, melatonin significantly enhanced the expression of connexin 26 (Cx26) and connexin 43 (Cx43) at mRNA and protein levels, but not that of connexin $30(\mathrm{Cx} 30)$ in $\mathrm{H}_{2} \mathrm{O}_{2}$-treated $\mathrm{HaCaT}$ cells. Of note, melatonin attenuated the phosphorylation of extracellular signal-regulated protein kinases (ERKs) more than p38 MAPK or JNK in $\mathrm{H}_{2} \mathrm{O}_{2}$-treated HaCaT cells. Conversely, ERK inhibitor PD98059 promoted the intercellular communication in $\mathrm{H}_{2} \mathrm{O}_{2}$-treated $\mathrm{HaCaT}$ cells. Furthermore, combined treatment of melatonin $(200 \mu \mathrm{M})$ and vitamin $\mathrm{C}(10 \mu \mathrm{g} / \mathrm{mL})$ significantly reduced ROS production in $\mathrm{H}_{2} \mathrm{O}_{2}$-treated HaCaT cells. Overall, these findings support the scientific evidences that melatonin facilitates gap junctional intercellular communication in $\mathrm{H}_{2} \mathrm{O}_{2}$-treated HaCaT keratinocyte cells via inhibition of connexin 26/43 and ERK as a potent chemopreventive agent.
\end{abstract}

\section{Introduction}

Gap junctional intercellular communication (GJIC) is an important biological mechanism to maintain homeostasis, growth, differentiation, and development of cells and tissues [1]. Gap junctions are made of two hemichannels, called connexons, and each in turn is composed of six molecules of the membrane-spanning connexin $(\mathrm{Cx})$ protein $[2,3]$.

The gap junctions of human keratinocytes include primarily $\mathrm{Cx} 43$, which is abundantly expressed within interfollicular epidermis, and Cx26, which is codistributed with Cx43 in skin [4]. Several studies showed that the downregulation of Cxs and phosphorylation of Cxs are involved in the carcinogenesis of the skin $[4,5]$. Cx43 is phosphorylated by several protein kinases, such as protein kinase $\mathrm{C}(\mathrm{PKC})$, casein kinase 1 , and mitogen-activated protein kinase (MAPK) $[3,6-8]$. Recent evidence suggests that the carcinogenicity of oxidative stress induced by $\mathrm{H}_{2} \mathrm{O}_{2}$ is attributable to the inhibition of GJIC [8-10].

Melatonin, an indoleamine ( $\mathrm{N}$-acetyl-5 methoxytryptamine), produced especially at night in the pineal gland [11, $12]$, has antioxidant $[13,14]$, anti-inflammatory $[15,16]$, antidepressant [17], and antitumor activities against various cancers [18-20]. Though melatonin was recently shown to regulate GJIC in chick astrocyte [21], mouse hepatocytes [22], and MCF-7 breast cancer cells [23, 24], the underlying molecular mechanism by melatonin via GJIC regulation in human keratinocyte HaCaT cells still remains unclear. Thus, in the present study, the molecular mechanism responsible for GJIC regulation by melatonin was examined in human 
keratinocyte HaCaT cells using the MTT assay, scrapeloading assay, RT-PCR, western blotting, and flow cytometric analysis for reactive oxygen species (ROS).

\section{Materials and Methods}

2.1. Chemicals and Reagents. Melatonin (molecular weight: 232), dimethylsulfoxide (DMSO), 3-(4,5-dimethylthiazol2-yl)-2,5-diphenyltetrazolium bromide (MTT), protease inhibitor cocktail, Lucifer Yellow, Trizol reagent, MMLV, Taq polymerase, vitamin $\mathrm{C}$, and 2,7-dichlorofluorescein diacetate (DCFDA) fluorescence dye were purchased from SigmaAldrich (St. Louis, MO, USA). Primers (Cx26, Cx30, and $\mathrm{Cx} 43$ ) were purchased from Cosmogenetech (Seoul, Republic of Korea). Dulbecco's Modified Eagle Medium (DMEM), fetal bovine serum (FBS), and antibiotic-antimycotic agent were obtained from Welgene (Daegu, Republic of Korea). Sodium dodecyl sulfate (SDS) was purchased from Amresco (Solon, OH, USA). RC DC protein assay kit was purchased from Bio-Rad (Hercules, CA, USA). Dimethylformamide was obtained from Merck KGaA (Darmstadt, Germany). Enhanced chemiluminescence (ECL) detection reagent was purchased from Amersham Pharmacia (Piscataway, NJ, USA). Phospho-JNK, JNK phospho-p38 MAPK, p38 MAPK, phospho-ERK, and ERK antibodies were obtained from Cell Signaling Technology (Danvers, MA, USA). Cx26, Cx30, $\mathrm{Cx} 43$, and phospho-Cx43 antibodies were purchased from Santa Cruz Biotechnology (Santa Cruz, CA, USA). $\beta$-actin was purchased from Sigma-Aldrich (St. Louis, MO, USA). Melatonin was dissolved in DMSO (2 M stock solution). In all experiments, DMSO concentration was kept below $0.2 \%$ $(\mathrm{v} / \mathrm{v})$ to remove the cytotoxic effect of solvent DMSO.

2.2. Cell Culture. Human keratinocyte HaCaT cells were purchased from American Type Culture Collection (Manassas, VA, USA) and maintained in DMEM supplemented with $10 \% \mathrm{FBS}$ and penicillin/streptomycin.

2.3. Cytotoxicity Assay. The cytotoxicity of melatonin was measured by MTT colorimetric assay. HaCaT cells were seeded onto 96-well microplates at a density of $1 \times 10^{4}$ cells per well and treated with various concentrations of melatonin for $24 \mathrm{~h}$. MTT working solution $(5 \mathrm{mg} / \mathrm{mL}$ in PBS) was added to each well and incubated at $37^{\circ} \mathrm{C}$ for $3 \mathrm{~h}$. The optical density (OD) was then measured at $570 \mathrm{~nm}$ using a microplate reader (Sunrise, TECAN, Männedorf, Switzerland). Cell viability was calculated as a percentage of viable cells in melatonin or $\mathrm{H}_{2} \mathrm{O}_{2}$-treated group versus untreated control by the following equation: cell viability $(\%)=[\mathrm{OD}($ melatonin $)-\mathrm{OD}($ blank $)] /[\mathrm{OD}($ Control $)-\mathrm{OD}$ (Blank)] $\times 100$.

2.4. Scrape-Loading Dye-Transfer Assay. GJIC of the cells was assessed by the scrape-loading dye-transfer (SLDT) technique described by EL-Fouly et al. [25] with some modifications. HaCaT cells (cell confluency; 80-90\%) incubated in $35 \mathrm{~mm}$ dishes for $24 \mathrm{~h}$ were treated with $\mathrm{H}_{2} \mathrm{O}_{2}$ $(300 \mu \mathrm{M})$ or melatonin (1 or $2 \mathrm{mM})$, respectively. Following incubation, the cells were washed twice with $2 \mathrm{~mL}$ of PBS.
Lucifer Yellow was added to the washed cells, and three scrapes were made with a surgical steel-bladed scalpel at lowlight intensities. Three scrapes were performed to ensure that the scrape traversed a large group of confluent cells. After $3 \mathrm{~min}$ incubation, the cells were washed with $10 \mathrm{~mL}$ of PBS and then fixed with $2 \mathrm{~mL}$ of a $4 \%$ formalin solution. The distance traveled by the dye in a direction perpendicular to the scrape was observed with an inverted Axio Axiovert S 100 fluorescent microscope (Carl Zeiss).

2.5. Total RNA Isolation and RT-PCR Analysis. Total RNA was prepared by using Trizol reagent according to the manufacturer's instructions. Total RNA $(1.0 \mu \mathrm{g})$ was reverse transcribed using MMLV reverse transcriptase (Promega, Madison, WI, USA) by incubation at $25^{\circ} \mathrm{C}$ for $10 \mathrm{~min}$, at $42^{\circ} \mathrm{C}$ for $60 \mathrm{~min}$, and at $99^{\circ} \mathrm{C}$ for $5 \mathrm{~min}$. The synthesized cDNA was amplified using TaKaRa Taq DNA polymerase ( TaKaRa Biotechnology, Shiga, Japan) and the following specific primers: CX26 (sense 5'-TCTTTTCCAGAGCAAACCGC$3^{\prime}$; antisense $5^{\prime}$-CTGGGCAATGAGTTAAACTGG-3' ), Cx30 (sense 5'-GCAGCATCTTTTTCCGAATC-3'; antisense 5'ATGCTCCTTTGTCAAGACGT-3'), CX43 (sense $5^{\prime}$-TACCATGCGACCAGTGGTGCGCT-3' ${ }^{\prime}$, antisense $5^{\prime}$-GAATTCTGGTTATCATCGGGGAA-3' ${ }^{\prime}$ ), and GAPDH (sense $5^{\prime}$ GTGGATATTGTTGCCATCA-3', antisense 5'-ACTCATACAGCACCTCAG-3' $3^{\prime}$ ). PCR conditions were 30 cycles of $96^{\circ} \mathrm{C}$ for $30 \mathrm{sec}, 55^{\circ} \mathrm{C}$ for $30 \mathrm{sec}$, and $72^{\circ} \mathrm{C}$ for $30 \mathrm{sec}$, followed by $5 \mathrm{~min}$ incubation at $72^{\circ} \mathrm{C}$. PCR products were run on $2 \%$ agarose gel and then stained with ethidium bromide (EtBr).

2.6. Measurement of Reactive Oxygen Species (ROS) Production. ROS level was measured using 2,7-dichlorofluorescein diacetate (DCFDA) fluorescence dye. Cells were incubated with $1 \mu \mathrm{M} \mathrm{DCFDA}$ at $37^{\circ} \mathrm{C}$ for $30 \mathrm{~min}$. Fluorescence intensity was measured by BD FACSCalibur flow cytometry (Becton Dickinson, Franklin Lakes, NJ).

2.7. Western Blotting. Cells $\left(1 \times 10^{6}\right.$ cells $\left./ \mathrm{mL}\right)$ were treated with various concentrations of melatonin $(0,1$, or $2 \mathrm{mM})$ for $24 \mathrm{~h}$, lyzed in lysis (50 mM Tris- $\mathrm{HCl}, \mathrm{pH} 7.4,150 \mathrm{mM} \mathrm{NaCl}$, $1 \%$ Triton X-100, 0.1\% SDS, 1 mM EDTA, $1 \mathrm{mM} \mathrm{Na} \mathrm{VO}_{4}$, $1 \mathrm{mM} \mathrm{NaF}$, and 1x protease inhibitor cocktail) on ice, and spun down at $14,000 \times \mathrm{g}$ for $20 \mathrm{~min}$ at $4^{\circ} \mathrm{C}$. The supernatants were collected and quantified for protein concentration by using RC DC protein assay kits (Bio-Rad, Hercules, CA, USA). The protein samples were separated on $4-12 \%$ NuPAGE Bis-Tris gels (Novex, Carlsbad, CA, USA) and transferred to a Hybond ECL transfer membrane for detection with antibodies for $\mathrm{Cx} 26, \mathrm{Cx} 30, \mathrm{Cx} 43$ and phosphorCx43 (Santa Cruz Biotechnologies, Santa Cruz, CA, USA), phospho-JNK, JNK, phospho-p38 MAPK, p38 MAPK, phospho-ERK, and ERK (Cell signaling Technology, Beverly, MA, USA), and $\beta$-actin (Sigma, St. Louis, MO, USA).

2.8. Statistical Analyses. All data were expressed as means \pm SD. The statistically significant differences between control and melatonin-treated groups were calculated by ANOVA test followed by a post hoc analysis (Tukey or Dunnett's 


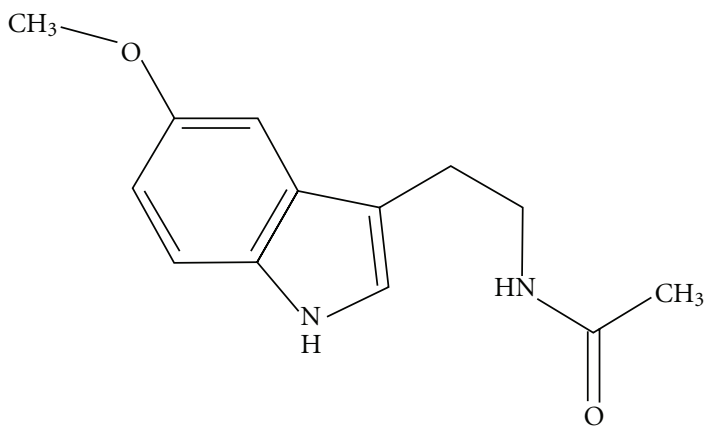

Melatonin (M.W. = 232)

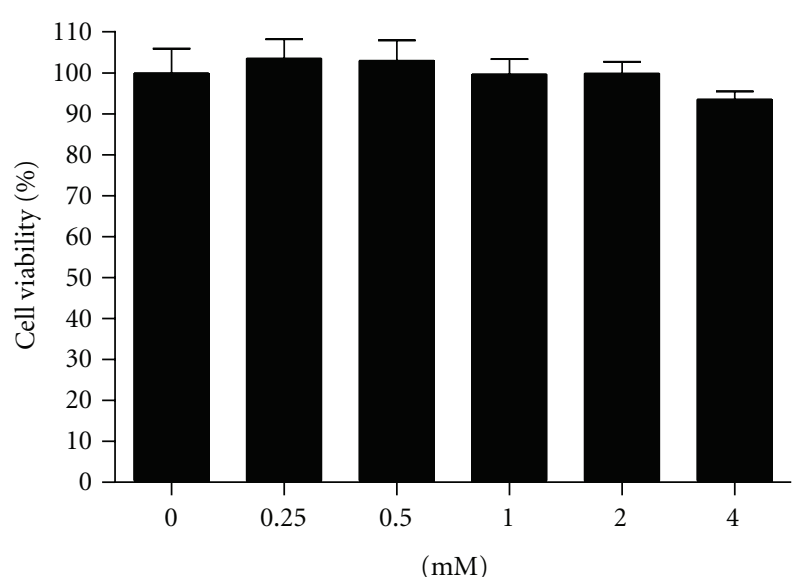

(b)

(a)

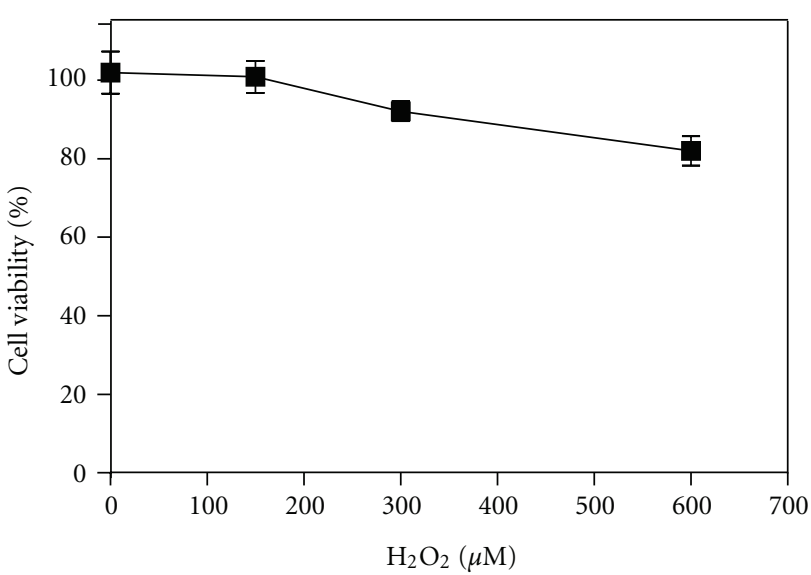

(c)

FIGURE 1: Chemical structure and cytotoxicity of melatonin. (a) Chemical structure of melatonin. Cytotoxicity of melatonin (b) and $\mathrm{H}_{2} \mathrm{O}_{2}$ (c) in $\mathrm{HaCaT}$ cells. Cytotoxicity of melatonin and $\mathrm{H}_{2} \mathrm{O}_{2}$ was evaluated in $\mathrm{HaCaT}$ cells by MTT assay. Cells were plated onto 96-well microplates $\left(1 \times 10^{4}\right.$ cells/well $)$ and treated with various concentrations of melatonin $(0,0.25,0.5,1,2$, or $4 \mathrm{mM})$ and $\mathrm{H}_{2} \mathrm{O}_{2}(0,150,300$, or $600 \mu \mathrm{M})$ for $24 \mathrm{~h}$. Data were expressed as means \pm SD of three independent experiments.

multiple-comparison test) using Prism software 5 (GraphPad Software, Inc., San Diego, CA, USA).

\section{Results}

3.1. Melatonin and $\mathrm{H}_{2} \mathrm{O}_{2}$ Exerted Weak Cytotoxicity in $\mathrm{HaCaT}$ Cells. To determine nontoxic concentrations of melatonin and $\mathrm{H}_{2} \mathrm{O}_{2}$, the cytotoxic effects of melatonin and $\mathrm{H}_{2} \mathrm{O}_{2}$ were evaluated in HaCaT cells by MTT assay. Cells were exposed to various concentrations of melatonin $(0,0.25,0.5,1,2$, or $4 \mathrm{mM})$ and $\mathrm{H}_{2} \mathrm{O}_{2}(0,150,300$, or $600 \mu \mathrm{M})$ for $24 \mathrm{~h}$, and then MTT assay was performed. As shown in Figures 1(b) and $1(\mathrm{c})$, melatonin and $\mathrm{H}_{2} \mathrm{O}_{2}$ showed weak cytotoxic effect in $\mathrm{HaCaT}$ cells. Thus, a concentration of $300 \mu \mathrm{M} \mathrm{H}_{2} \mathrm{O}_{2}$ was used for all experiments.

3.2. Melatonin Reduced ROS Production and Facilitated the Decreased GJIC Activity in $\mathrm{H}_{2} \mathrm{O}_{2}$-Treated HaCaT Cells. $\mathrm{H}_{2} \mathrm{O}_{2}$ is well known to produce free radicals to inhibit gap junctional intercellular communication [26]. As shown in Figure 2(a), melatonin reduced ROS production to $5.83 \%$ compared to $\mathrm{H}_{2} \mathrm{O}_{2}$-treated control (22\%) in HaCaT cells. Consistently, melatonin enhanced intercellular communication disturbed by $\mathrm{H}_{2} \mathrm{O}_{2}$ in $\mathrm{HaCaT}$ cells by scrape-loading dye-transfer assay as shown in Figures 2(c) and 2(d).

3.3. Melatonin Significantly Enhanced the Expression of Cx26 and Cx43 at mRNA and Protein Levels, but Not That of $\mathrm{C} \times 30$ in $\mathrm{H}_{2} \mathrm{O}_{2}$-Treated $\mathrm{HaCaT}$ Cells. The phosphorylation of the gap junction protein $\mathrm{Cx} 43$ is directly associated to functional GJIC [27]. To investigate the effect of melatonin on connexins at mRNA and protein levels in $\mathrm{H}_{2} \mathrm{O}_{2}$-treated HaCaT cells, RT-PCR and western blot analyses were carried out. As shown in Figures 3(a) and 3(b), mRNA levels of $\mathrm{Cx} 26$ and $\mathrm{Cx} 43$ were reduced by $\mathrm{H}_{2} \mathrm{O}_{2}$-alone treatment, while melatonin enhanced the mRNA level of them in $\mathrm{H}_{2} \mathrm{O}_{2}$ treated HaCaT cells. mRNA level of $\mathrm{Cx} 30$ did not change in $\mathrm{H}_{2} \mathrm{O}_{2}$ - or melatonin-treated cells. Consistently, melatonin increased the protein level of $\mathrm{Cx} 26$ and $\mathrm{Cx} 43$ in $\mathrm{H}_{2} \mathrm{O}_{2}$-treated $\mathrm{HaCaT}$ cells (Figures 3(d) and 3(e)). We also observed that melatonin suppressed the phosphorylation of $\mathrm{Cx} 43$ in $\mathrm{H}_{2} \mathrm{O}_{2}$ treated HaCaT cells (Figure 3(c)). 

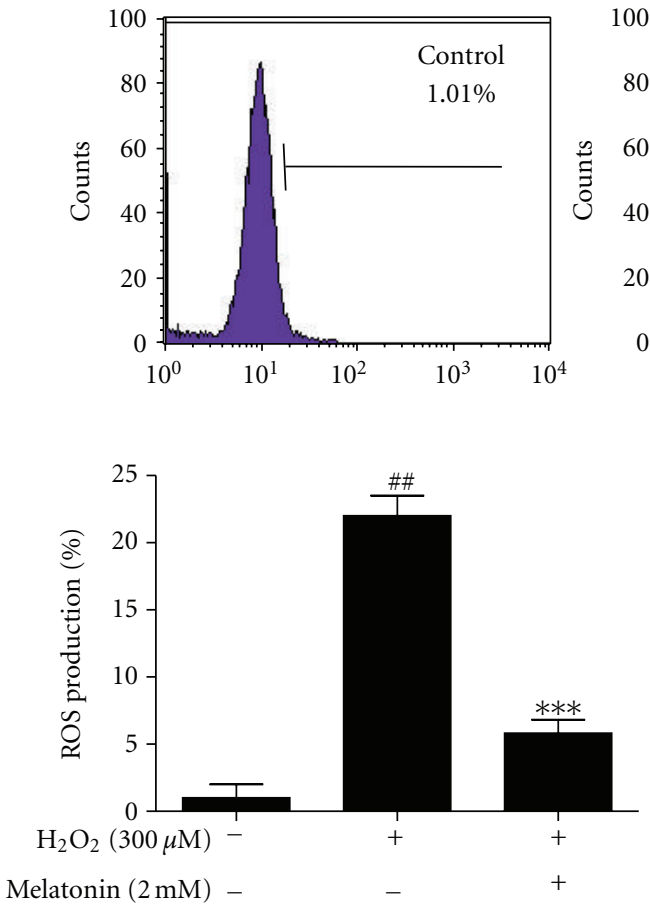

(b)

Melatonin $(2 \mathrm{mM})$

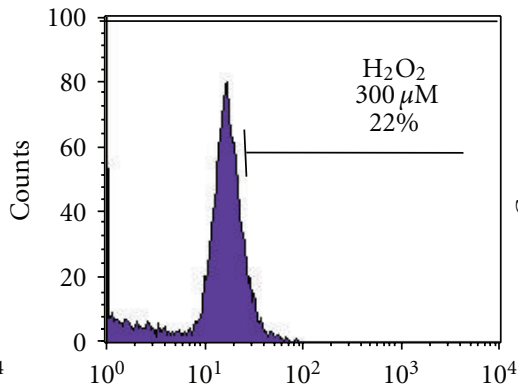

(a)

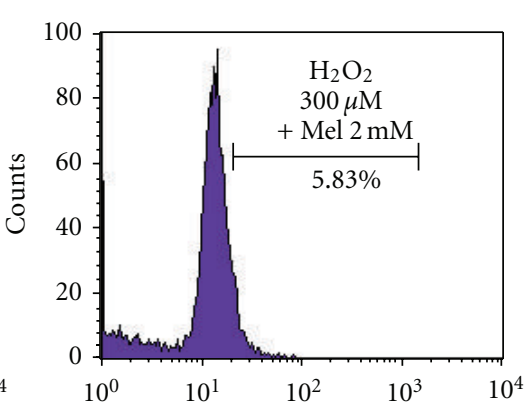

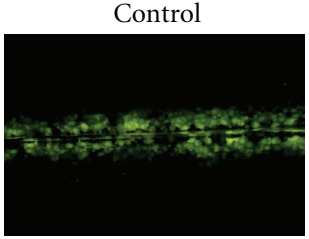$$
225
$$

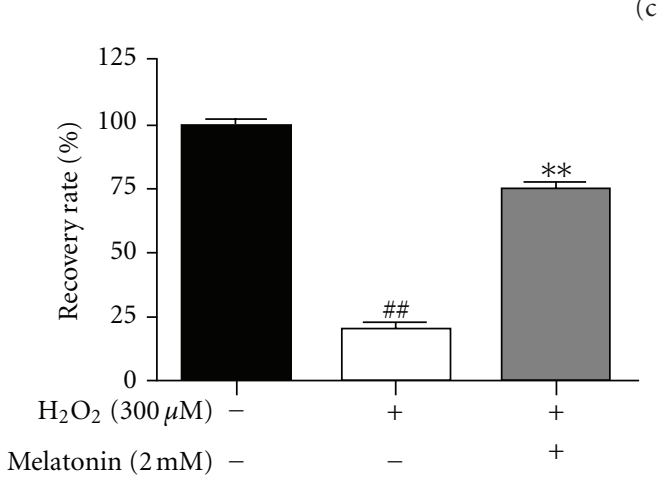

$\mathrm{H}_{2} \mathrm{O}_{2} 300 \mu \mathrm{M}$ + melatonin $2 \mathrm{mM}$

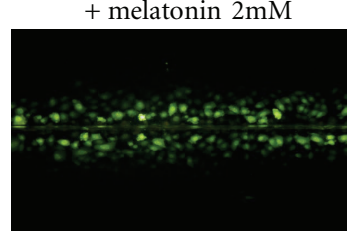

(c)

(d)

FIGURE 2: Melatonin reduced ROS production and facilitated the decreased GJIC activity in $\mathrm{H}_{2} \mathrm{O}_{2}$-treated HaCaT cells. (a) Cells were exposed to $\mathrm{H}_{2} \mathrm{O}_{2}(300 \mu \mathrm{M})$ with or without melatonin $(2 \mathrm{mM})$ for $24 \mathrm{~h}$. ROS generation (\%) was measured using ROS-sensitive fluorometric probe 2,7-dichlorofluorescein diacetate (DCFDA) by flow cytometric analysis. (b) Quantified graph for ROS production. Data represent means \pm SD. ${ }^{\#} P<0.01$ versus untreated control. ${ }^{* * *} P<0.001$ versus melatonin treated cells. (c) GJIC was assessed using the scrape-loading/dyetransfer (SL/DT) method under an inverted fluorescence microscope (100x). (d) Quantification of recovery rate.

3.4. Melatonin Significantly Decreased the Phosphorylation of ERK Alone, but Not p38 MAPK or JNK in $\mathrm{H}_{2} \mathrm{O}_{2}$-Treated $\mathrm{HaCaT}$ Cells. The effect of melatonin on MAPK signaling was investigated in $\mathrm{H}_{2} \mathrm{O}_{2}$-treated $\mathrm{HaCaT}$ cells. Melatonin attenuated the phosphorylation of ERK, but did not significantly affect that of p38 MAPK and JNK in $\mathrm{H}_{2} \mathrm{O}_{2}$-treated $\mathrm{HaCaT}$ cells, while $\mathrm{H}_{2} \mathrm{O}_{2}$ activated the phosphorylation of ERK, p38, and JNK proteins as shown in Figures 4(a) and 4(b). Next, in order to confirm that the GJIC by $\mathrm{H}_{2} \mathrm{O}_{2}$ is mediated by ERK pathway, we used the ERK inhibitor PD98059. As shown in Figures 4(c) and 4(d), ERK inhibitor PD98059 effectively recovered the decreased activity of GJIC in $\mathrm{H}_{2} \mathrm{O}_{2}$-treated $\mathrm{HaCaT}$ cells.
3.5. Combined Treatment of Melatonin and Vitamin C at Low Concentrations Exerted the Synergy in Reducing ROS Production in $\mathrm{H}_{2} \mathrm{O}_{2}$-Treated $\mathrm{HaCaT}$ Cells. In order to evaluate the synergistic effect of melatonin with other antioxidant, we used vitamin C. As shown in Figure 5(a), melatonin $(200 \mu \mathrm{M})$ or vitamin $\mathrm{C}(10 \mu \mathrm{g} / \mathrm{mL})$ alone at low concentration did not affect $\mathrm{Cx} 34$ in $\mathrm{H}_{2} \mathrm{O}_{2}$-treated HaCaT cells. In contrast, combined treatment of melatonin and vitamin $\mathrm{C}$ promoted the expression of $\mathrm{Cx} 34$. Similarly, though melatonin at $2 \mathrm{mM}$ suppressed ROS generation induced by $\mathrm{H}_{2} \mathrm{O}_{2}$, low concentration $(200 \mu \mathrm{M})$ of melatonin did not affect ROS production as in Figure 5(b). As shown in Figure 5(b), melatonin $(200 \mu \mathrm{M})$ or vitamin $\mathrm{C}(10 \mu \mathrm{g})$ alone did not affect 


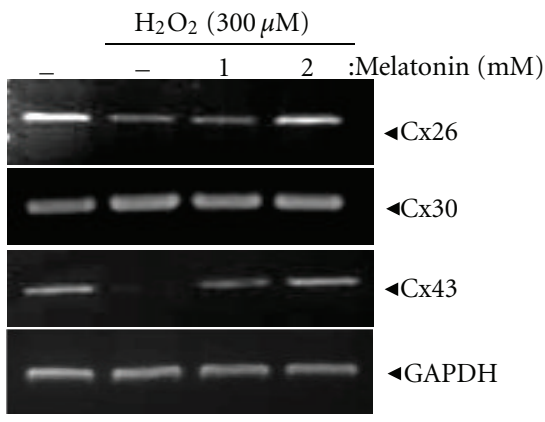

(a)

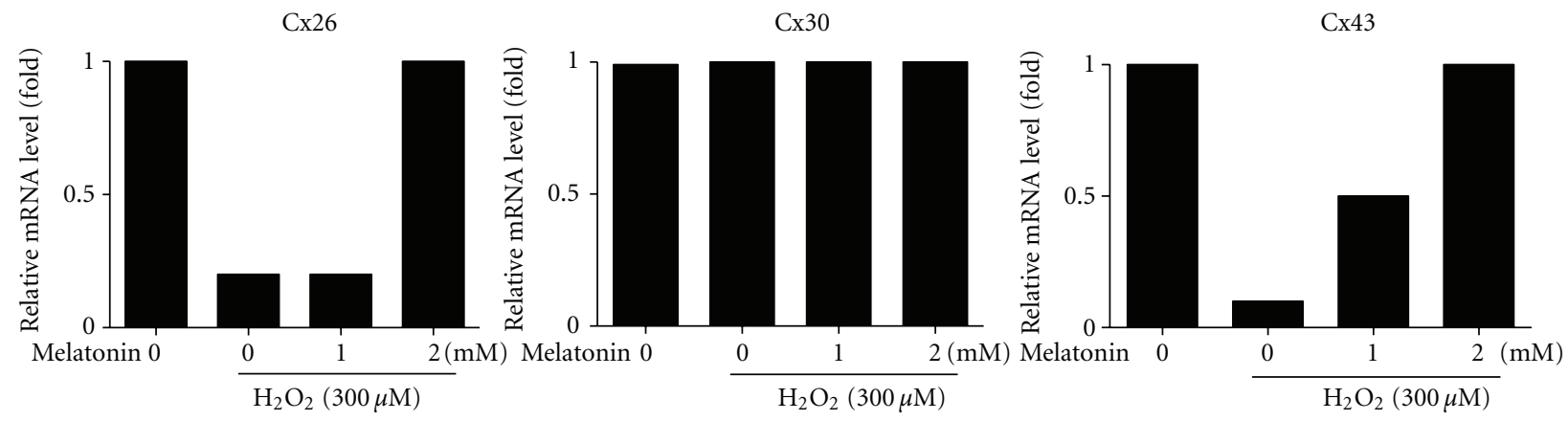

(b)

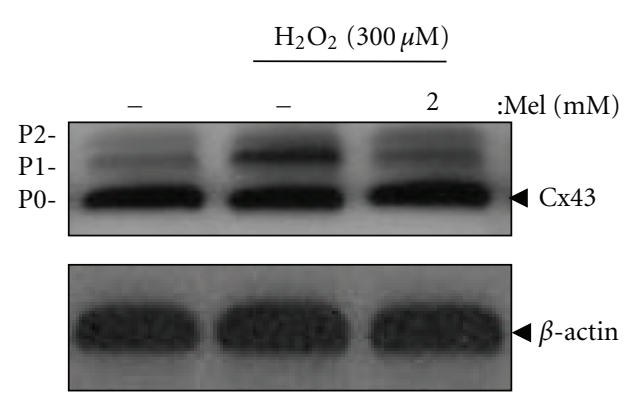

(c)

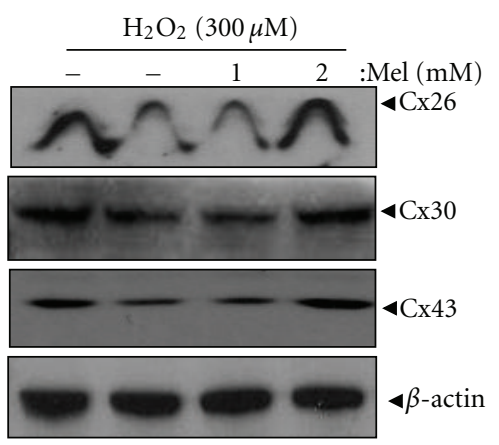

(d)
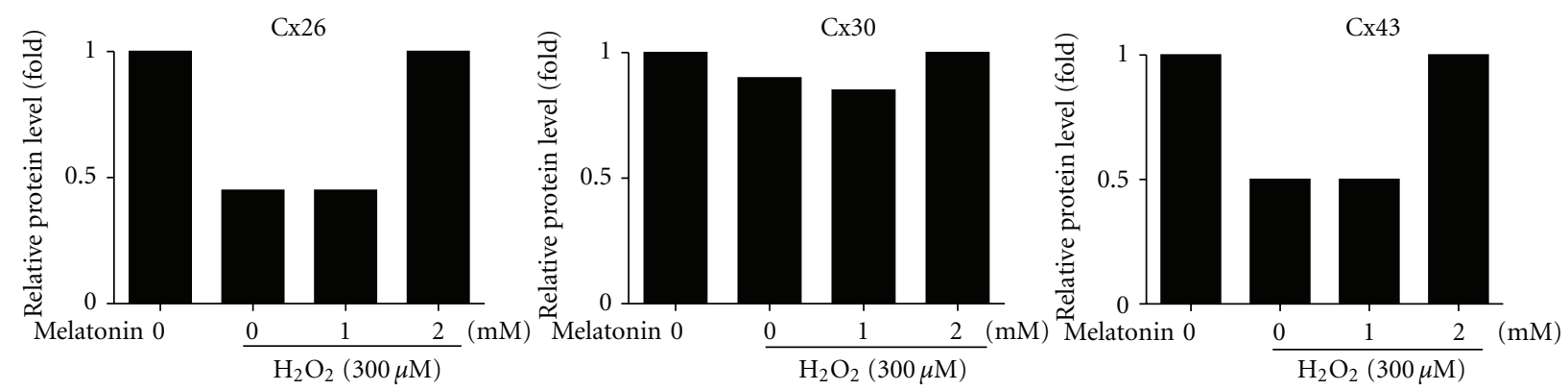

(e)

FIgure 3: Melatonin significantly enhanced the expression of $\mathrm{Cx} 26$ and $\mathrm{Cx} 43$ at mRNA and protein levels, but not that of $\mathrm{Cx}_{30}$ in $\mathrm{H}_{2} \mathrm{O}_{2}$ treated HaCaT cells. (a) Cells were exposed to $\mathrm{H}_{2} \mathrm{O}_{2}(300 \mu \mathrm{M})$ with or without melatonin ( 1 or $\left.2 \mathrm{mM}\right)$ for $24 \mathrm{~h}$. (a) mRNAs expressions of Cx26, Cx30, and Cx43 were analyzed by RT-PCR. Grapes represent relative level of Cx26, Cx30, and Cx43/GAPDH. (b) Quantification of mRNAs expression. Phosphorylation of $\mathrm{Cx} 43$ (c) and protein expressions of Cx26, Cx30, and Cx43 (d) in melatonin- $\mathrm{H}_{2} \mathrm{O}_{2}$-treated cells were analyzed by western blot. (e) Grapes represent relative level of Cx26, Cx30, and Cx43/ $\beta$-actin. 


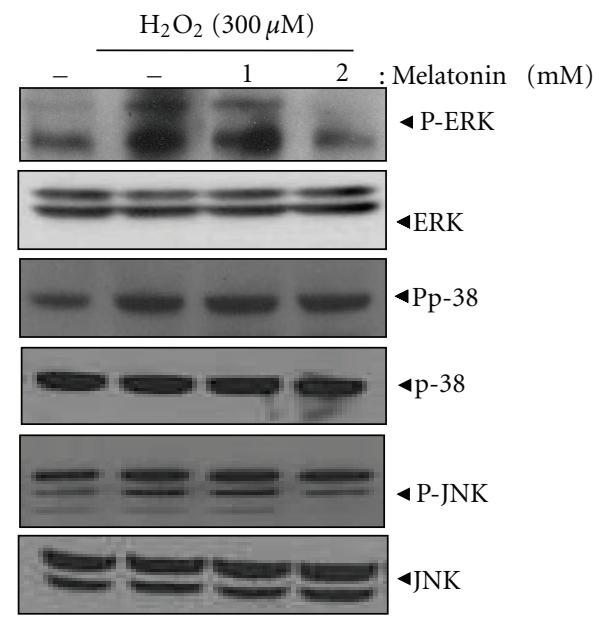

(a)

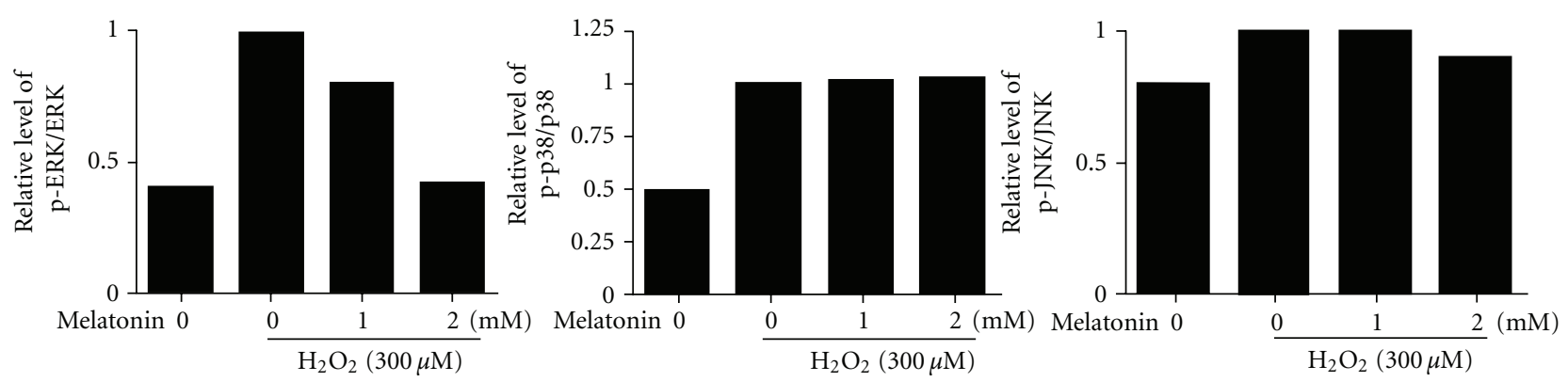

(b)

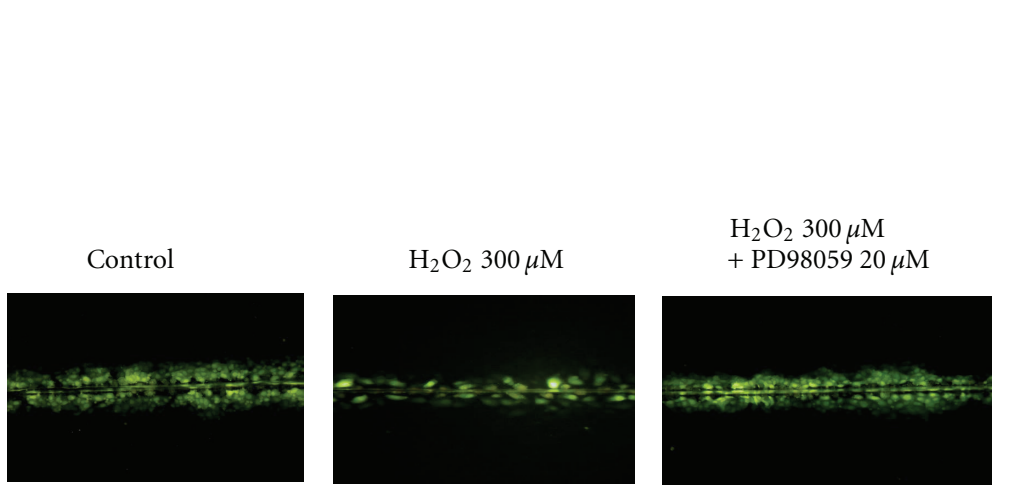

(c)

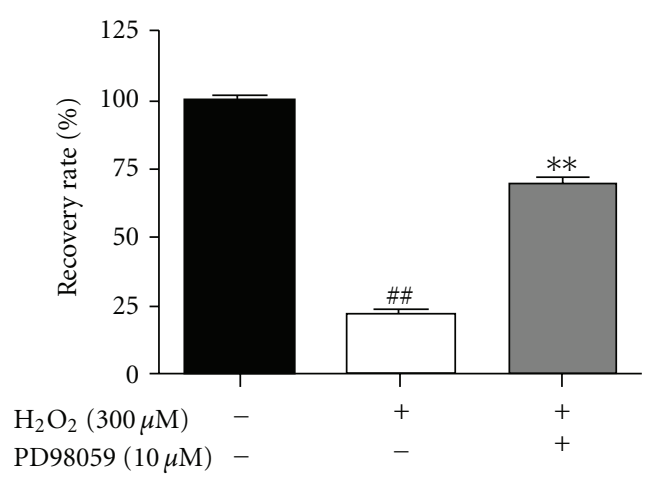

(d)

FIGURE 4: Melatonin significantly decreased the phosphorylation of ERK alone, but not p38 MAPK or JNK in $\mathrm{H}_{2} \mathrm{O}_{2}$-treated $\mathrm{HaCaT}$ cells. Cells were exposed to $\mathrm{H}_{2} \mathrm{O}_{2}(300 \mu \mathrm{M})$ with or without melatonin $(1$ or $2 \mathrm{mM})$ for $24 \mathrm{~h}$. (a) Western blotting was performed for phosphoERK, ERK, phospho-p38, p38, phospho-JNK, and JNK. (b) Graphs represent relative level of phospho-ERK/ERK, phospho-p38/p38, and phospho-JNK/JNK. (c) Effect of ERK inhibitor PD98059 on GJIC using the SL/DT method. (d) Quantification of recovery rate.

ROS production, but combination of melatonin and vitamin $\mathrm{C}$ significantly reduced ROS production to $16.15 \%$ compared to $\mathrm{H}_{2} \mathrm{O}_{2}$-treated control $(23.56 \%)$.

\section{Discussion}

$\mathrm{H}_{2} \mathrm{O}_{2}$ plays an important role in the multistep process of carcinogenesis and directly promotes transformation in many in vivo and in vitro model systems [28-30]. In the present study, melatonin suppressed ROS production and facilitated $\mathrm{H}_{2} \mathrm{O}_{2}$-mediated inhibition of GJIC in HaCaT cells, implying the antioxidant and anti-carcinogenic potential of melatonin, which was supported by previous studies that the carcinogenicity of $\mathrm{H}_{2} \mathrm{O}_{2}$ is attributable to the inhibition of GJIC [31]. Likewise, antioxidants such as vitamin $\mathrm{C}$ and quercetin protect against the disruption of GJIC induced by $\mathrm{H}_{2} \mathrm{O}_{2}$ [32].

There are several lines of evidences that malignant lesions reveal abnormal expression of connexins and decreased GJIC [33-35]. The function of GIC can be modulated at the 


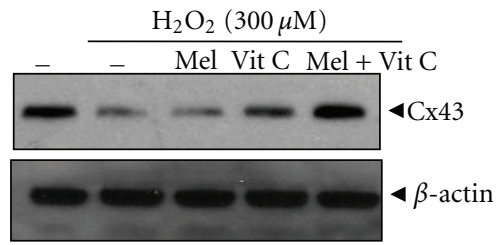

(a)
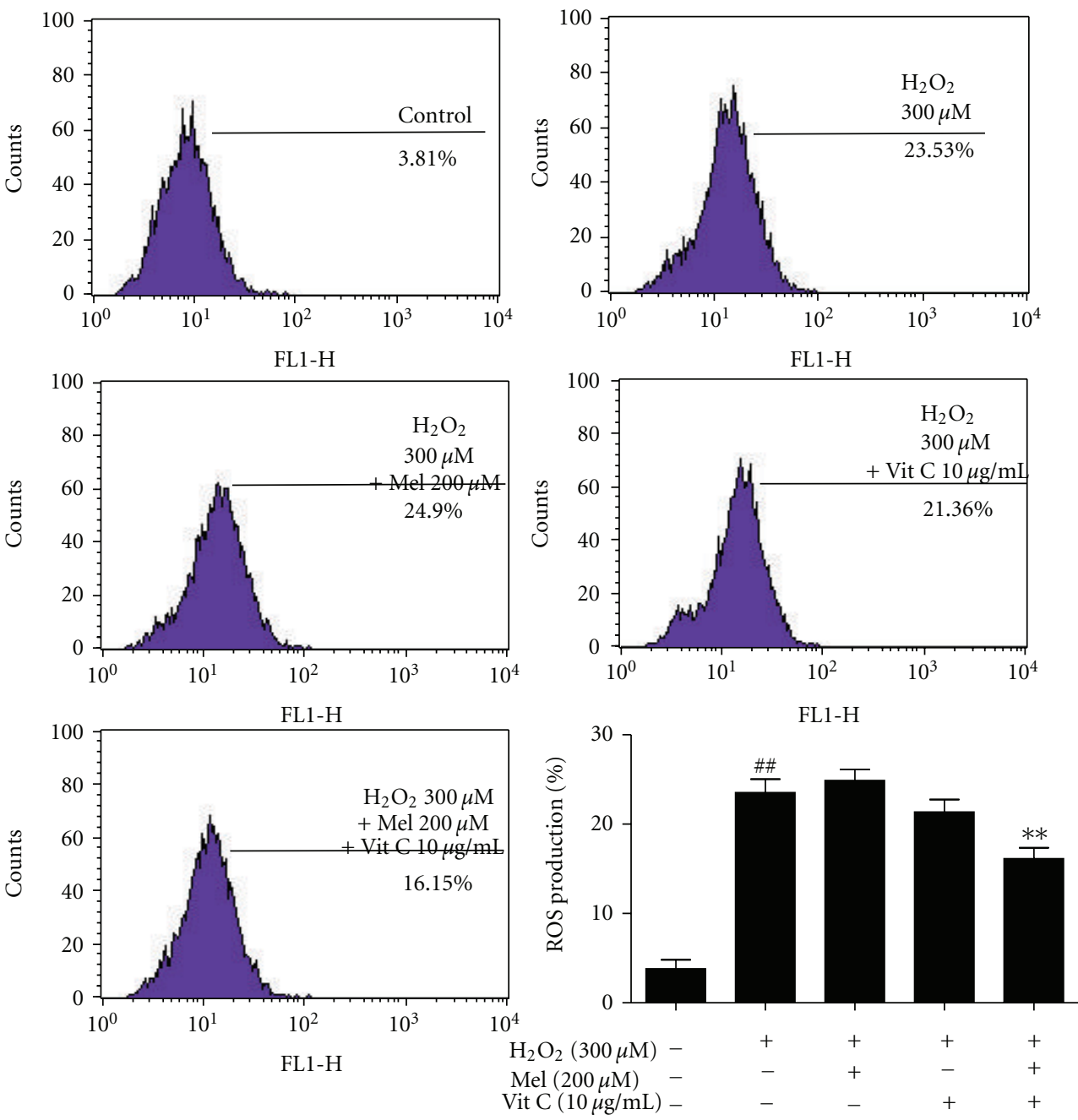

(b)

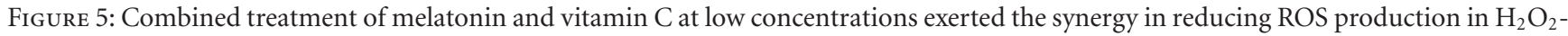
treated $\mathrm{HaCaT}$ cells. $\mathrm{H}_{2} \mathrm{O}_{2}$-treated $\mathrm{HaCaT}$ cells were exposed in the absence or presence of melatonin $(200 \mu \mathrm{M})$, vitamin C $(10 \mu \mathrm{g} / \mathrm{mL})$, and melatonin plus vitamin $\mathrm{C}$ for $24 \mathrm{~h}$. (a) Western blotting was performed for Cx43 and $\beta$-actin. (b) ROS generation (\%) was measured using ROS-sensitive fluorometric probe 2,7-dichlorofluorescein diacetate (DCFDA) by flow cytometric analysis. Graph represents quantification for ROS production.

multi-stages during the turnover of connexins by transcriptional, translational, and posttranscriptional mechanisms. Hence, prevention or inhibition of decreased GJIC can be an important target for cancer therapy. As suggested, $\mathrm{H}_{2} \mathrm{O}_{2}$ induced downregulation of connexins, thereby disrupting the GJIC system [5]. Here we found that melatonin recovered the reduced phosphorylation of $\mathrm{Cx} 26$ and $\mathrm{Cx} 43$ induced by $\mathrm{H}_{2} \mathrm{O}_{2}$ at protein and mRNA levels, but not that of
$\mathrm{Cx} 30$ in $\mathrm{H}_{2} \mathrm{O}_{2}$-treated $\mathrm{HaCaT}$ cells, indicating that melatonin regulates GJIC via activation of Cx26 and Cx43 signaling.

MAPKs are considered to play important roles in GJIC [36]. Also, ROS-activated MAPK cascades phosphorylate the various proteins involved in cell growth and development [37]. Previous studies revealed that $\mathrm{H}_{2} \mathrm{O}_{2}$-dependent ERK and p38 kinase activation lead to depressed GJIC and enhanced connexin degradation [36]. However, in the 


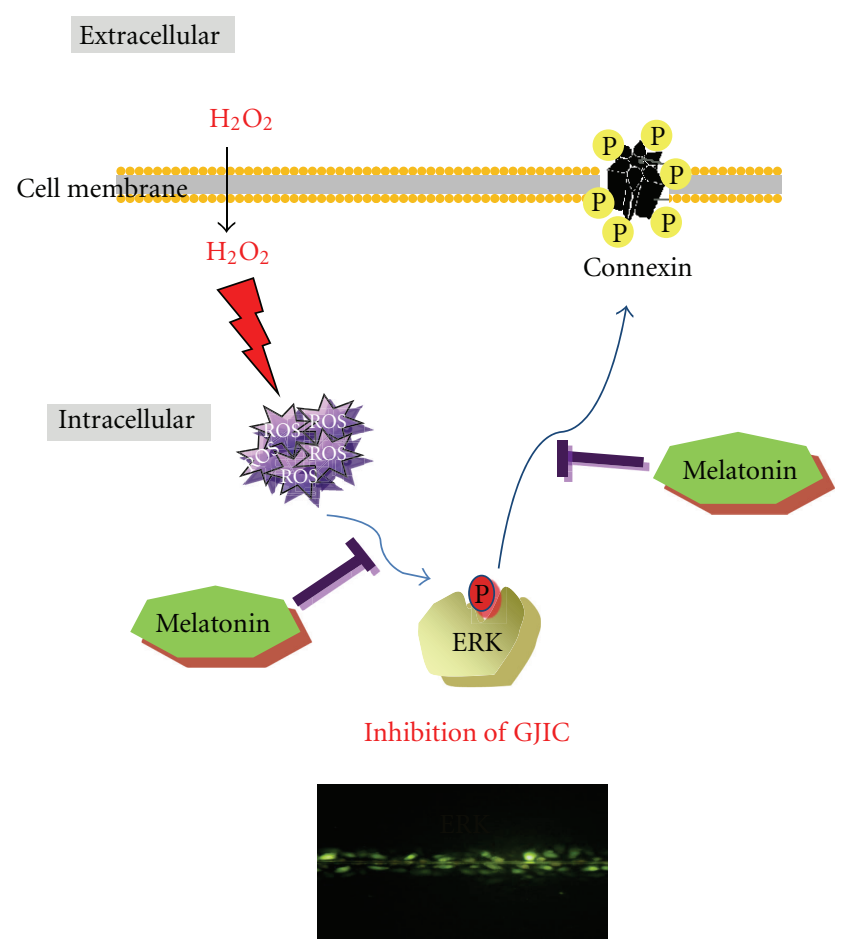

FIgURE 6: Molecular mechanism of melatonin facilitated GJIC in $\mathrm{H}_{2} \mathrm{O}_{2}$-treated $\mathrm{HaCaT}$ cells.

current study, melatonin significantly decreased the phosphorylation of ERK alone, but not p38 MAPK or JNK. Furthermore, ERK inhibitor PD98059 effectively recovered the lowered activity of GJIC in $\mathrm{H}_{2} \mathrm{O}_{2}$-treated HaCaT cells, suggesting the critical role of ERK in recovering the decreased GJIC activity by $\mathrm{H}_{2} \mathrm{O}_{2}$. Interestingly, combined treatment of melatonin $(200 \mu \mathrm{M})$ and vitamin $\mathrm{C}(10 \mu \mathrm{g} / \mathrm{mL})$ that do not affect ROS production significantly reduced ROS production in $\mathrm{H}_{2} \mathrm{O}_{2}$-treated $\mathrm{HaCaT}$ cells, implying the synergistic effect of melatonin and vitamin $\mathrm{C}$ at low concentrations. However, it is also required to confirm this synergistic effect in small animals or humans in the near future.

In summary, melatonin showed weak cytotoxicity in $\mathrm{HaCaT}$ cells, reduced ROS production, recovered the disturbed GJIC, enhanced the expression of Cx26 and Cx43 at mRNA and protein levels, suppressed the phosphorylation of ERK, and enhanced synergy with vitamin $\mathrm{C}$ in $\mathrm{H}_{2} \mathrm{O}_{2}$-treated $\mathrm{HaCaT}$ cells (Figure 6). Overall, our findings suggest that melatonin recovers decreased GJIC via enhancement of Cx26 and $\mathrm{Cx} 43$ and inhibition of ROS production and ERK phosphorylation.

\section{Authors' Contribution}

H.-J. Lee and S.-H. Kim conceived and coordinated the studies, designed the experiments, and drafted the paper. H.-J. Lee, H.-J. Lee, and E. J. Sohn performed experiments and statistical analyses and analyzed data. E.-O. Lee, J.-H. Kim, and M.-H. Lee analyzed data. H.-J. Lee and S.-H. Kim analyzed data and edited the paper. All authors read and approved the final paper. H.-J. Lee and M.-H. Lee are contributed equally to this paper.

\section{Acknowledgments}

This work was supported by a postdoctoral Fellowship Grant from the Kyung Hee University in 2011 (KHU-20110687) and the Korea Science and Engineering Foundation (KOSEF) Grant funded by the Korea government (MEST) (no. 20120005755) and BioGreen 21 Program (no. PJ007998).

\section{References}

[1] W. R. Lowenstein, "Junctional intercellular communication and the control of growth," Biochimica et Biophysica Acta, vol. 560, no. 1, pp. 1-65, 1979.

[2] G. Zampighi, "On the structure of isolated junctions between communicating cells," In Vitro, vol. 16, no. 12, pp. 1018-1028, 1980.

[3] K. M. Lee, J. Y. Kwon, K. W. Lee, and H. J. Lee, "Ascorbic acid 6-palmitate suppresses gap-junctional intercellular communication through phosphorylation of connexin 43 via activation of the MEK-ERK pathway," Mutation Research, vol. 660, no. $1-2$, pp. 51-56, 2009.

[4] D. Salomon, E. Masgrau, S. Vischer et al., "Topography in mammalian connexins in human skin," Journal of Investigative Dermatology, vol. 103, no. 2, pp. 240-247, 1994.

[5] J. E. Trosko and R. J. Ruch, "Cell-cell communication in carcinogenesis," Frontiers in Bioscience, vol. 3, pp. d208-d236, 1998.

[6] P. D. Lampe and A. F. Lau, "The effects of connexin phosphorylation on gap junctional communication," International Journal of Biochemistry and Cell Biology, vol. 36, no. 7, pp. 1171-1186, 2004.

[7] A. F. Lau, W. E. Kurata, M. Y. Kanemitsu et al., "Regulation of connexin 43 function by activated tyrosine protein kinases," Journal of Bioenergetics and Biomembranes, vol. 28, no. 4, pp. 359-368, 1996.

[8] J. H. Cho, S. D. Cho, H. Hu et al., "The roles of ERK1/2 and p38 MAP kinases in the preventive mechanisms of mushroom Phellinus linteus against the inhibition of gap junctional intercellular communication by hydrogen peroxide," Carcinogenesis, vol. 23, no. 7, pp. 1163-1169, 2002.

[9] B. L. Upham, M. Gužvić, J. Scott et al., "Inhibition of gap junctional intercellular communication and activation of mitogen-activated protein kinase by tumor-promoting organic peroxides and protection by resveratrol," Nutrition and Cancer, vol. 57, no. 1, pp. 38-47, 2007.

[10] R. P. Huang, A. Peng, A. Golard et al., "Hydrogen peroxide promotes transformation of rat liver non-neoplastic epithelial cells through activation of epidermal growth factor receptor," Molecular Carcinogenesis, vol. 30, no. 4, pp. 209-217, 2001.

[11] R. J. Reiter, D. X. Tan, and L. Fuentes-Broto, "Melatonin: a multitasking molecule," Progress in Brain Research, vol. 181, pp. 127-151, 2010.

[12] J. H. Stehle, A. Saade, O. Rawashdeh et al., "A survey of molecular details in the human pineal gland in the light of phylogeny, structure, function and chronobiological diseases," Journal of Pineal Research, vol. 51, no. 1, pp. 17-43, 2011.

[13] D. Bonnefont-Rousselot, F. Collin, D. Jore, and M. GardèsAlbert, "Reaction mechanism of melatonin oxidation by reactive oxygen species in vitro," Journal of Pineal Research, vol. 50, no. 3, pp. 328-335, 2011. 
[14] A. Galano, D. X. Tan, and R. J. Reiter, "Melatonin as a natural ally against oxidative stress: a physicochemical examination," Journal of Pineal Research, vol. 51, no. 1, pp. 1-16, 2011.

[15] U. I. Wu, F. D. Mai, J. N. Sheu et al., "Melatonin inhibits microglial activation, reduces pro-inflammatory cytokine levels, and rescues hippocampal neurons of adult rats with acute Klebsiella pneumoniae meningitis," Journal of Pineal Research, vol. 50, no. 2, pp. 159-170, 2011.

[16] O. Belyaev, T. Herzog, J. Munding et al., "Protective role of endogenous melatonin in the early course of human acute pancreatitis," Journal of Pineal Research, vol. 50, no. 1, pp. 7177, 2011.

[17] V. Raghavendra, G. Kaur, and S. K. Kulkarni, "Anti-depressant action of melatonin in chronic forced swimming-induced behavioral despair in mice, role of peripheral benzodiazepine receptor modulation," European Neuropsychopharmacology, vol. 10, no. 6, pp. 473-481, 2000.

[18] S. E. Lee, S. J. Kim, J. P. Youn, S. Y. Hwang, C. S. Park, and Y. S. Park, "MicroRNA and gene expression analysis of melatoninexposed human breast cancer cell lines indicating involvement of the anticancer effect," Journal of Pineal Research, vol. 51, no. 3, pp. 345-352, 2011.

[19] W. Koh, S. J. Jeong, H. J. Lee et al., "Melatonin promotes puromycin-induced apoptosis with activation of caspase-3 and $5^{\prime}$-adenosine monophosphate-activated kinase-alpha in human leukemia HL-60 cells," Journal of Pineal Research, vol. 50, no. 4, pp. 367-373, 2011.

[20] B. Jung-Hynes, T. L. Schmit, S. R. Reagan-Shaw, I. A. Siddiqui, H. Mukhtar, and N. Ahmad, "Melatonin, a novel Sirt1 inhibitor, imparts antiproliferative effects against prostate cancer in vitro in culture and in vivo in TRAMP model," Journal of Pineal Research, vol. 50, no. 2, pp. 140-149, 2011.

[21] I. M. McGonnell, C. R. Green, C. Tickle, and D. L. Becker, "Connexin43 gap junction protein plays an essential role in morphogenesis of the embryonic chick face," Developmental Dynamics, vol. 222, no. 3, pp. 420-438, 2001.

[22] M. Vinken, T. Henkens, E. De Rop, J. Fraczek, T. Vanhaecke, and V. Rogiers, "Biology and pathobiology of gap junctional channels in hepatocytes," Hepatology, vol. 47, no. 3, pp. 10771088, 2008.

[23] Y. Zhou, M. T. Mi, J. D. Zhu, and Q. Y. Zhang, "Effects of lovastatin on proliferation and gap junctional intercellular communication of human breast cancer cell MCF-7," Ai Zheng, vol. 22, no. 3, pp. 257-261, 2003.

[24] G. Gakhar, D. Schrempp, and T. A. Nguyen, "Regulation of gap junctional intercellular communication by TCDD in HMEC and MCF-7 breast cancer cells," Toxicology and Applied Pharmacology, vol. 235, no. 2, pp. 171-181, 2009.

[25] M. H. El-Fouly, J. E. Trosko, and C. C. Chang, "Scrape-loading and dye transfer. A rapid and simple technique to study gap junctional intercellular communication," Experimental Cell Research, vol. 168, no. 2, pp. 422-430, 1987.

[26] B. L. Upham, K. S. Kang, H. Y. Cho, and J. E. Trosko, "Hydrogen peroxide inhibits gap junctional intercellular communication in glutathione sufficient but not glutathione deficient cells," Carcinogenesis, vol. 18, no. 1, pp. 37-42, 1997.

[27] M. R. Wilson, T. W. Close, and J. E. Trosko, "Cell population dynamics (apoptosis, mitosis, and cell-cell communication) during disruption of homeostasis," Experimental Cell Research, vol. 254, no. 2, pp. 257-268, 2000.

[28] M. Okamoto and R. Oyasu, "Transformation in vitro of a nontumorigenic rat urothelial cell line by tumor necrosis factora," Laboratory Investigation, vol. 77, no. 2, pp. 139-144, 1997.

[29] R. J. Ruch, S. J. Cheng, and J. E. Klaunig, "Prevention of cytotoxicity and inhibition of intercellular communication by antioxidant catechins isolated from Chinese green tea," Carcinogenesis, vol. 10, no. 6, pp. 1003-1008, 1989.

[30] D. Muehlematter, R. Larsson, and P. Cerutti, "Active oxygen induced DNA strand breakage and poly ADP-ribosylation in promotable and non-promotable JB6 mouse epidermal cells," Carcinogenesis, vol. 9, no. 2, pp. 239-245, 1988.

[31] R. P. Huang, A. Peng, M. Z. Hossain, Y. Fan, A. Jagdale, and A. L. Boynton, "Tumor promotion by hydrogen peroxide in rat liver epithelial cells," Carcinogenesis, vol. 20, no. 3, pp. 485492, 1999.

[32] K. W. Lee, H. J. Lee, K. S. Kang, and C. Y. Lee, "Preventive effects of vitamin C on carcinogenesis," The Lancet, vol. 359, no. 9301, p. 172, 2002.

[33] S. Sulkowski, M. Sulkowska, and E. Skrzydlewska, "Gap junctional intercellular communication and carcinogenesis," Polish Journal of Pathology, vol. 50, no. 4, pp. 227-233, 1999.

[34] A. Temme, A. Buchmann, H. D. Gabriel, E. Nelles, M. Schwarz, and K. Willecke, "High incidence of spontaneous and chemically induced liver tumors in mice deficient for connexin32," Current Biology, vol. 7, no. 9, pp. 713-716, 1997.

[35] Y. Kamibayashi, Y. Oyamada, M. Mori, and M. Oyamada, "Aberrant expression of gap junction proteins (connexins) is associated with tumor progression during multistage mouse skin carcinogenesis in vivo," Carcinogenesis, vol. 16, no. 6, pp. 1287-1297, 1995.

[36] J. W. Hwang, J. S. Park, E. H. Jo et al., "Chinese cabbage extracts and sulforaphane can protect $\mathrm{H}_{2} \mathrm{O}_{2}$-induced inhibition of gap junctional intercellular communication through the inactivation of ERK1/2 and p38 MAP kinases," Journal of Agricultural and Food Chemistry, vol. 53, no. 21, pp. 82058210, 2005.

[37] P. A. Kuruganti, R. D. Wurster, and P. A. Lucchesi, "Mitogen activated protein kinase activation and oxidant signaling in astrocytoma cells," Journal of Neuro-Oncology, vol. 56, no. 2, pp. 109-117, 2002. 


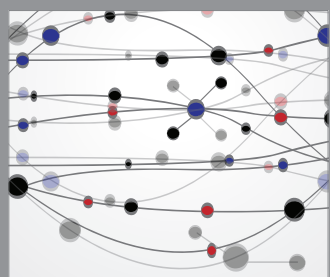

The Scientific World Journal
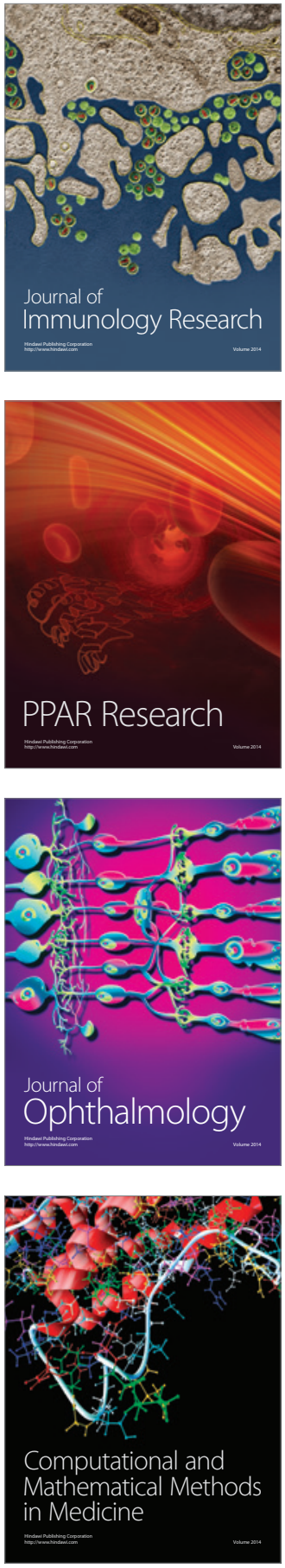

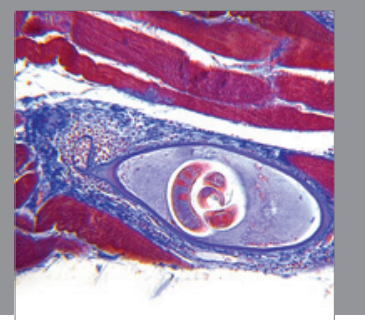

Gastroenterology

Research and Practice
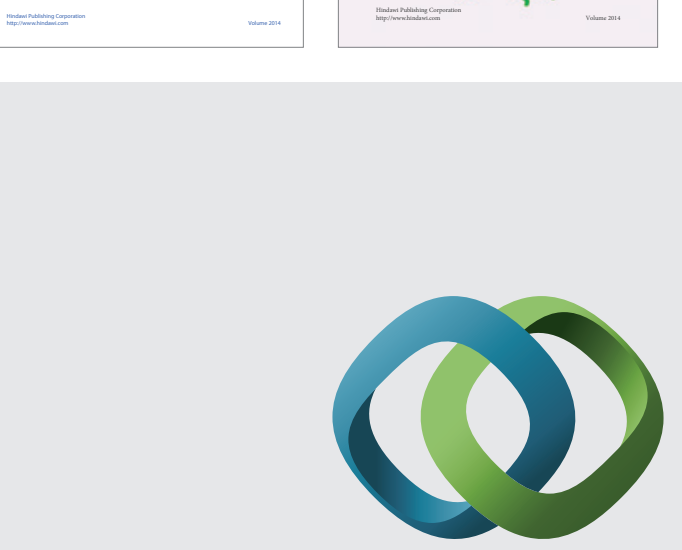

\section{Hindawi}

Submit your manuscripts at

http://www.hindawi.com
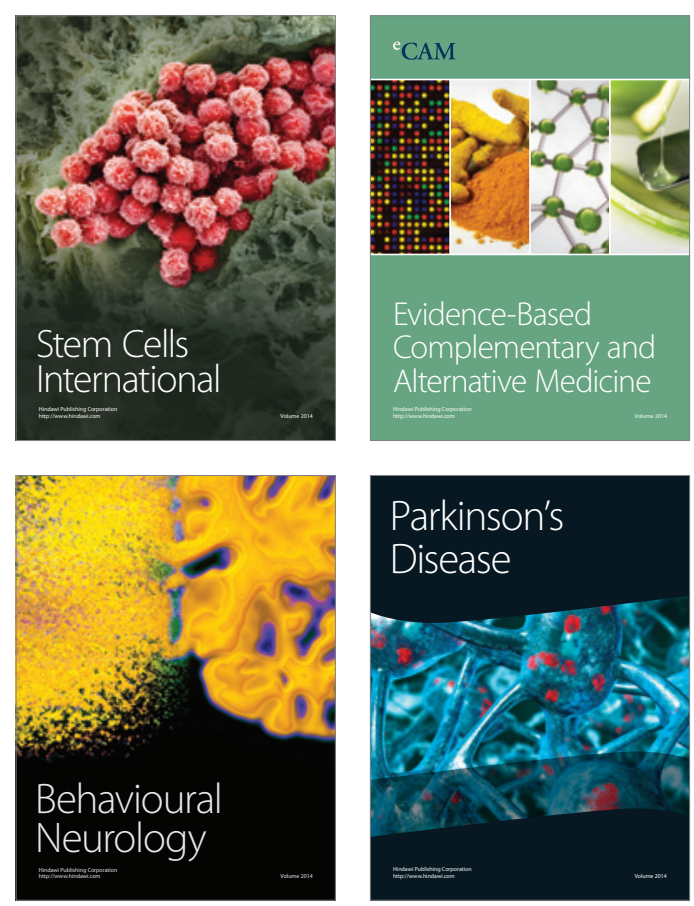

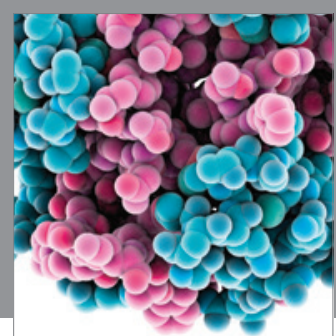

Journal of
Diabetes Research

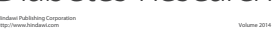

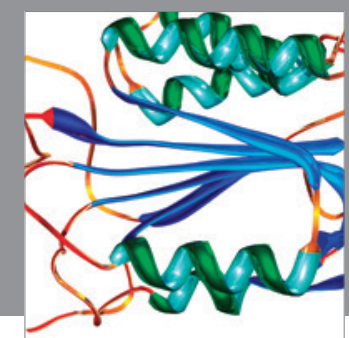

Disease Markers
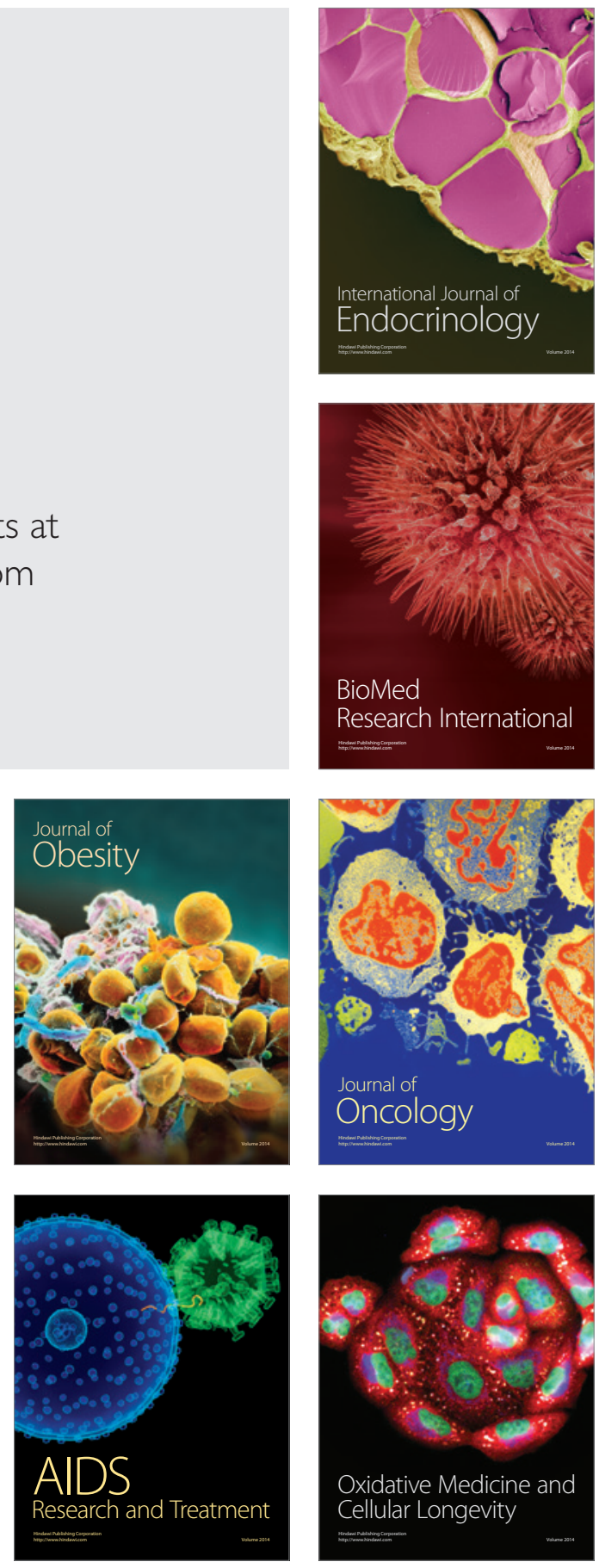